\title{
The Organisation of Comprehensive Remote Support of Pre-school Children with Speech Disorders
}

\author{
Natalia Borisova ${ }^{1},{ }^{*}$ Tatyana Zakharova ${ }^{1}$, Larisa Pepik ${ }^{1}$ \\ ${ }^{1}$ Cherepovets State University, Cherepovets, Russia \\ *Email: borisova-n-a@mail.ru
}

\begin{abstract}
The article is devoted to the issues of assisting children with speech disorders in current conditions, considering the emerging social and epidemiological risks. The authors consider the problem of organising and improving the effectiveness of comprehensive support for children of this category. The article's content presents the results of studying the activities of teachers, specialists and parents on the organisation of comprehensive support for children with speech disorders. The data obtained indicate the presence of significant factors preventing the provision of systemic and comprehensive assistance necessary for children with speech disorders. These factors, in particular, include the lack of a sufficient number of specialists, the inconsistency of their training with modern requirements, the difficulties of interdisciplinary and interdepartmental interaction, territorial inaccessibility of correctional and educational services. To overcome these shortcomings, a remote model of comprehensive support for children with speech disorders was developed, its main structural components were disclosed. The article presents the possibilities of implementing a comprehensive support model for children with speech disorders in traditional and remote formats.
\end{abstract}

Keywords: Comprehensive remote support, Support model, Children with speech disorders, Interdisciplinary interaction, Interdepartmental interaction, Participants in the educational process.

\section{INTRODUCTION}

In the last decade in our country and abroad, there has been a steady trend of increasing the number of children with disabilities in physical and mental development. According to the UN, there are approximately 450 million people with developmental disabilities globally, including children with various forms of speech pathology. In this regard, most developed countries have developed their assistance system for persons with disabilities, which is characterised by differentiation by nosological groups and age levels (K.A. Erickson [1], T. Jonsson [2], M.Perez-Pereira [3]).

A distinctive feature of the last decades is the widespread introduction of special and inclusive practices to reduce the distance between children with disabilities and their normally developing peers. The effectiveness of the modern system of assistance to children with developmental disabilities depends on a combination of factors such as coordination of efforts of specialists from different departments, cooperation with the family of children, territorial accessibility of services provided (N.A.Borisova, L.A. Pepik [4], O.A. Denisova, V.V. Zaboltina, T.V. Zakharova [5-8]).

\section{THE PROBLEM AND PURPOSE OF THE STUDY}

The general and special education system is currently actively searching for new technologies that provide flexibility and variability in providing medical, psychological and pedagogical assistance to children with disabilities and disabilities. This becomes especially relevant in conditions of increased social and epidemiological risks: insufficient number and territorial remoteness of organisations providing correctional and educational services to persons with disabilities and their families; financial unavailability of certain specific services; difficulties in organising interdisciplinary and interdepartmental interaction; isolation regime in a pandemic. All this prevents the complete and timely 
inclusion in the comprehensive support and assistance system of all children in need with disabilities, including those with speech pathology.

The presence of even mild deviations in speech development in pre-schoolers leaves an imprint on the formation of their sensory, intellectual and affectivevolitional spheres, prevents further assimilation of the general education school program, limits the possibilities of socialisation (N.S. Zhukova, E.M. Mastyukova, T.B. Filicheva) [9]. In this regard, there is a need to apply an integrated approach to the support of children of this category, including the interaction of specialists of different profiles (medical, correctional, psychological and pedagogical), which is difficult in the conditions of these risks. One of the solutions to this problem is developing and implementing a variable model of comprehensive support for children with speech disorders, which can be presented in both traditional and remote formats.

The purpose of the study is to identify the features of the readiness of participants in the educational process to organise comprehensive support for children with speech disorders and develop a model of comprehensive remote support for this category of children.

It is assumed that the answers to these questions will help achieve the goal and contribute to improving the system of assistance to children with disabilities in the context of modern challenges.

\section{MATERIALS AND METHODS}

The study was conducted based on pre-school educational organisations (PEO) in Vologda of the Vologda region. It was attended by children with speech disorders (phonetic underdevelopment of speech, phonetic and phonemic underdevelopment of speech), attending general education groups; their parents, teachers and specialists.

The diagnostic program of the experimental study included the study of the activities of teachers and specialists in the organisation of comprehensive support for children with speech disorders, questioning of parents and speech therapy examination of children. The following diagnostic techniques were used:

- studying the documentation of a pre-school educational organisation (educational programs and plans, local acts on the main issues of the organisation and implementation of educational activities of preschool educational institutions, the nomenclature of cases);

- monitoring the activities of educators, music director, physical education instructor, speech therapist; conversation with the educator;
- test method "Diagnostics of oral speech" by T.A. Fotekova (to assess the speech development of preschool children) [10];

- questionnaire for parents "Identification of the role of parents in the formation of speech activity of preschool children", developed based on materials proposed by O.V. Solodyankina [11].

\section{RESEARCH RESULTS}

The analysis of the documentation showed that it did not reflect the substantive and organisational issues of comprehensive support for children with speech disorders, a model of support was not developed and does not function, which significantly hindered the implementation of an individual approach to children with speech disorders in general education groups. It was also revealed that there were no specialists and teachers in the staffing table to ensure the full functioning of the integrated support model.

The results obtained in observing the activities of educators, music director, physical education instructor, speech therapist made it possible to divide all teachers and specialists into three groups according to the selected criteria.

Teachers and specialists assigned to the first group showed a high level of methodological training, manifested in high-quality training and conducting classes, considering the individual characteristics of children with speech disorders. Teachers of this group know the techniques of prevention of speech disorders and actively participate in the joint activities of specialists of the organisation to eliminate speech disorders of the child. They are engaged in selfeducation, conduct educational, explanatory work.

Teachers and specialists of the second group demonstrated an average level of methodological training. An individual approach to a child with speech disorders is not always carried out. There was a partial mastery of the methods of organising preventive work and episodic participation in joint activities of specialists in all fields to eliminate children's speech disorders. Teachers of this group are engaged in selfeducation and conduct educational work periodically, haphazardly.

The third group consisted of teachers and specialists who showed a low level of methodological training. Their classes did not meet the requirements of organising direct educational activities. Teachers of this group are not guided in the methods of organising preventive work; do not initiate participation in joint activities of specialists in all fields aimed at eliminating speech disorders of children; do not engage in selfeducation, do not conduct educational work. 
Table 1 presents the results of the speech therapy examination of pre-schoolers. Summarising these data, we can say that the first group of children (22.75-30 points) demonstrated the highest level of success in completing tasks. They are characterised by accurate and correct reproduction of syllables at the pace of presentation, accurate and proper execution of articulation exercises, the correct pronunciation of sounds and syllabic structure of the word, precise reproduction of sentences, correct formation of word forms, the ability to compose a story based on a series of paintings and retell the text.

In the second group of children (15.2-22.5 points), there are comparisons of syllables during their reproduction, slow or strenuous performance of exercises on display, distortion or replacement of sounds in spontaneous speech, syllabic reproduction of words of complex syllabic structure, omission of individual words without distortion of the sentence structure, self-correction in case of incorrect formation of word forms, difficulties in reproducing cause-andeffect relationships.

Children of the third group (7.75-15 points) rearrange syllables, replace and skip them when playing; search for articulation positions for a long time, distort or skip sounds in all speech situations, distort the sound-syllabic structure of words, cut parts of a sentence, distort the meaning and structure of a sentence when repeating it, incorrectly form word forms, significantly distort the meaning of the story.

For children of the fourth group (0-7.5 points), it is characterised by the complete impossibility of reproducing syllables and articulatory movements; distortion, omission or replacement of a large number of sounds; the inability to reproduce words of complex syllabic structure, simple sentences, the formation of word forms, a retelling of the text.

In general, the results of the speech therapy examination of children indicate the need for comprehensive support by teachers and specialists.

The survey results of parents of children with speech disorders showed that most families (90\%) are interested in the child's speech development. They pay attention to violations of sound pronunciation, stuttering, rearrangements, slurred speech. Such parents are concerned and are looking for ways to solve this problem (they turn to a speech therapist, neurologist, psychologist, engage in self-education, independently try to eliminate speech disorders in children). $10 \%$ of families are not concerned about children's speech disorders, considering it an age norm. These parents do not turn to specialists for advice; they believe that the problem will resolve itself.

Analysing the parents' answers about the comprehensive support of the child, it can be noted that most families $(60 \%)$ understand it as the cooperation of teachers and pre-school specialists in solving the child's problems. The other parents found it difficult to answer this question. Most respondents $(40 \%)$ do not know about the existence of a model of comprehensive support for a child with speech disorders in their preschool. Still, everyone is interested in creating this model and is ready to participate in its development and implementation in this pre-school organisation.

Thus, summarising the results of the data obtained, it should be concluded that parents, knowing about the existence of speech problems in the child and wanting to help him, do not always understand how to implement this in practice. Creating a comprehensive support model with the direct active participation of parents in its implementation will help solve this problem.

An analysis of educational organisations' activities in the experimental study showed that the existing work system to accompany children with speech disorders could not be successfully implemented in current conditions. These conditions are the inability to receive free speech therapist services due to his absence in the staffing of these educational organisations; the lack of interdisciplinary and interdepartmental relations with organisations providing support services; long-term stay of families in self-isolation due to the deterioration of the epidemiological situation, which limited the possibility of children receiving specialist services.

Table 1. Distribution of children according to the results of speech therapy examination (\%)

\begin{tabular}{|c|c|c|c|c|}
\hline \multirow{2}{*}{ Groups of children } & \multicolumn{4}{|c|}{ Number of children } \\
\cline { 2 - 5 } & $\begin{array}{c}\text { Sensori-motor level } \\
\text { of speech }\end{array}$ & $\begin{array}{c}\text { the gramma-tical } \\
\text { structure of speech }\end{array}$ & $\begin{array}{c}\text { Vocabu-lary and } \\
\text { word formation skills }\end{array}$ & coherent speech \\
\hline Group 1 & $50 \%$ & 0 & 0 & $55 \%$ \\
\hline Group 2 & $50 \%$ & $55 \%$ & $50 \%$ & $25 \%$ \\
\hline Group 3 & 0 & $45 \%$ & $50 \%$ & $10 \%$ \\
\hline Group 4 & 0 & 0 & 0 & $10 \%$ \\
\hline
\end{tabular}




\section{RESULTS DISCUSSION}

Based on the results of the study, a model of comprehensive remote support for pre-school children with speech disorders was developed, including the following components: the purpose, objectives and directions of support; stages of speech therapy examination and correctional speech therapy work; algorithm and family-centred model of interaction between teachers and specialists; remote resource centre.

The comprehensive support model for a senior preschool child with speech disorders was developed based on the principles of child and family support (territorial and financial accessibility, consistency, responsibility and continuity). The successful functioning of the model is possible if several conditions are met (organisation of an accessible environment, creation of safe conditions for people with speech disorders; an interdisciplinary approach to the teamwork of specialists; use of modern educational technologies; staffing of comprehensive support for a child with speech disorders).

The purpose of accompanying children with speech disorders is to create conditions conducive to their adaptation, learning, development, integration into society following individual characteristics of psychophysical development, assistance and support to the family.

The main tasks of comprehensive support include:

- Prevention of secondary disorders and possible problems of child development

- Assistance the child and his family solve urgent development, training, and socialisation problems.

- Methodological and technological support of educational programs.

- Formation of psychological and pedagogical competence of specialists, parents and teachers.

The directions of child and family support are:

- diagnostic direction within which diagnostic activity is carried out;

- correctional and developmental direction provides assistance in choosing an individual educational route based on interdepartmental interaction; development and implementation of corrective and developmental programs in working with older pre-school children with speech disorders;

- the advisory direction involves the implementation of special training programs for parents and their inclusion in the correctional and pedagogical process;

- the information and educational direction support public initiatives aimed at improving the guarantees of the free development of the child under his capabilities.
The most crucial component of the presented model is a remote resource centre, the main task of which is to coordinate the interaction of a pre-school educational organisation with services of various departmental affiliation participating in the system of comprehensive support for children with speech disorders (psychological, pedagogical, speech therapy, social, medical). Such a centre allows parents to make an appointment remotely and receive timely advice from the right specialist, even if he is absent from the staff of the educational organisation. In addition, a remote resource centre is indispensable in cases where it is necessary to coordinate specialists' interaction in implementing an individual correctional program. This is especially important in the context of social and epidemiological risks that lead to inaccessibility of correctional and educational services for families and limitations of interdisciplinary and interdepartmental interaction for specialists.

\section{CONCLUSION}

The way to represent the problem of support in education in the form of a model is critical and is currently considered one of the most significant factors in education development. The development of various support models for children with speech disorders is dictated by regional conditions (requests, resources, traditions, etc.). Different goals, tasks and opportunities of pre-school educational organisations require variability in the organisation of comprehensive support services. Such a model should consist of complementary links and reflect the result of the transition from isolated pedagogical support for the child and his family to a system of their comprehensive support.

Comprehensive psychological, medical and pedagogical support for children with speech disorders should be carried out through the interaction of participants in the educational process. The main goal of such interaction is to improve the quality of education and create favourable conditions for correcting the physical, mental and psychological health of children, their full development.

During the empirical study, the absence of structural components of comprehensive support for children with speech disorders was revealed (there is no teacher-psychologist, social pedagogue, medical workers in the staff schedule); problems of interaction of participants in the educational process.

The research work carried out made it possible to substantiate and develop a model of comprehensive support for children with speech disorders, which includes the following components: principles, conditions, directions of support; stages of speech therapy examination and correctional speech therapy 
work, an algorithm for interaction with the family; a remote resource centre.

Thus, in the presented study, it was possible to identify the features of the organisation of comprehensive support for older pre-school children with speech disorders in conditions of social and epidemiological risks.

\section{REFERENCES}

[1] K.A. Erickson, Literacy in early intervention for children with visual impairments: insights from individual cases, Journal of Visual Impairment \& Blindness 101(2) (2007) 80-95.

[2] T. Jonsson, Inclusive education. Interregional Programme for Disabled People, United Nations Development Programme, Geneve, 1994, 198 p.

[3] M. Perez-Pereira, Language development and social interaction in blind children, N.Y.: Psychology Press, 2006, 197 p.

[4] N.A. Borisova, L.A. Pepik, Assessment of the existing system of assistance to children with severe developmental disabilities from the perspective of the family, Proceedings of the IX International Scientific and Practical Conference "Actual problems of correctional pedagogy and special psychology", Cherepovets, November 2627, 2015, Cherepovets: Cherepovets State University [Ocenka sushchestvuyushchej sistemy pomoshchi detyam s tyazhyolymi narusheniyami razvitiya $s$ pozicii sem'i, Materialy IX Mezhdunarodnoj nauchno-prakticheskoj konferencii "Aktual'nye problemy korrekcionnoj pedagogiki i special'noj psihologii", Cherepovec, 26-27 noyabrya 2015 g., Cherepovec: Cherepoveckij gosudarstvennyj universitet], 2015, pp. 24-26.

[5] Development and implementation of adapted preschool education programs for children with disabilities: methodological recommendations. Part 1, edited by V.V. Zaboltina, T.V. Zakharova, scientific editor O.A. Denisova, Cherepovets: ChSU [Razrabotka i realizaciya adaptirovannyh programm doshkol'nogo obrazovaniya dlya detej s ogranichennymi vozmozhnostyami zdorov'ya: metodicheskie rekomendacii. CH. 1, pod red. V.V. Zaboltinoj, T.V. Zaharovoj, nauch. red. O.A. Denisova, CHerepovec: CHGU], 2018, 357 p.

[6] Development and implementation of adapted preschool education programs for children with disabilities: methodological recommendations. Part 2, edited by V.V. Zaboltina, T.V. Zakharova, scientific editor O.A. Denisova, Cherepovets:
ChSU [Razrabotka i realizaciya adaptirovannyh programm doshkol'nogo obrazovaniya dlya detej s ogranichennymi vozmozhnostyami zdorov'ya: metodicheskie rekomendacii. CH. 2, pod red. V.V. Zaboltinoj, T.V. Zaharovoj, nauch. red. O.A. Denisova, Cherepovec: CHGU], 2018, 114 p.

[7] Development of a model for introducing inclusive education in a pre-school educational institution: methodological recommendations, edited by V.V. Zaboltina, T.V. Zakharova, Cherepovets: ChSU [Razrabotka modeli vnedreniya inklyuzivnogo obrazovaniya v doshkol'nom obrazovatel'nom uchrezhdenii: metodicheskie rekomendacii, pod redakciej V.V. Zaboltinoj, T.V. Zaharovoj, CHerepovec: CHGU], 2020, 328 p.

[8] Special family pedagogy: a textbook, edited by V.I. Seliverstov, O.A. Denisova, L.M. Kobrina [Special'naya semejnaya pedagogika: uchebnoe posobie, pod redakciej V.I. Seliverstova, O.A. Denisovoj, L.M. Kobrinoj], M.: Humanitar. pub. centre VLADOS [Gumanitar. izd. centr VLADOS], 2009, 358 p.

[9] T.B. Filicheva, E.M. Mastyukova, N.S. Zhukova, Overcoming the general underdevelopment of speech in pre-schoolers [Preodolenie obshchego nedorazvitiya rechi u doshkol'nikov], M.: Enlightenment [Prosveshchenie], 1990, 239 p.

[10] L.I. Peresleni, T.A. Fotekova, Features of cognitive activity of younger school children with speech underdevelopment and mental retardation [Osobennosti poznavatel'noj deyatel'nosti mladshih shkol'nikov s nedorazvitiem rechi i s zaderzhkoj psihicheskogo razvitiya], Defectology [Defektologiya] 5 (1993) 3-10.

[11] O.V. Solodyankina, Education of a child with disabilities in the family [Vospitanie rebenka s ogranichennymi vozmozhnostyami zdorov'ya v sem'e], Moscow: ARKTI, 2007, 80 p. 